\title{
Recovery patterns and a linguistic therapy model of Sundanese- Indonesian bilingual aphasia: A neurolinguistic study
}

\author{
Riki Nasrullah, Dadang Suganda*, Wagiati, and Sugeng Riyanto \\ Faculty of Cultural Sciences, Universitas Padjadjaran, Jl. Raya Bandung Sumedang KM.21, \\ Kabupaten Sumedang, Jawa Barat 45363
}

\begin{tabular}{|c|c|}
\hline $\begin{array}{l}\text { ABSTRACT } \\
\text { This study observed a 54-year-old patient with Sundan } \\
\text { brain hospital in Jakarta, Indonesia. He underwent a spe } \\
\text { his second language (Indonesian) during the first } 2 \text { wee } \\
\text { to his both languages simultaneously for one and a hal } \\
\text { conducted by using two approaches, namely, a theor } \\
\text { approach. In terms of the theory, the approach used in t } \\
\text { the methodology, the approach is analytic-descriptive } \\
\text { been diagnosed with having expressive-receptive ap } \\
\text { evaluations of his competence in his two languages (dur } \\
\text { post-onset) showed an interesting recovery pattern. In } \\
\text { post-onset), it was found that the patient showed a nonp } \\
\text { language) recovered earlier than Sundanese (the firs } \\
\text { evaluation result (a month post-onset), it was found tha } \\
\text { languages showed a parallel recovery; the proficiency i } \\
\text { been given treatment in the therapy showed a recove } \\
\text { though Sundanese had not been given any treatment at a } \\
\text { track record of this patient showed that Indonesian had a } \\
\text { Sundanese, and this is correlated with the recovery proce }\end{array}$ & $\begin{array}{l}\text { donesian bilingual aphasia at one } \\
\text { erapy with the treatment given to } \\
\text { post-onset, and received treatment } \\
\text { ths post-onset. This research was } \\
\text { approach and a methodological } \\
\text { udy is neurolinguistic. In terms of } \\
\text { cohort method. The patient had } \\
\text { in both languages. Three-time } \\
\text { e period of one and a half months } \\
\text { irst evaluation result (two weeks } \\
\text { recovery; Indonesian (the second } \\
\text { suage). However, in the second } \\
\text { mprovement in proficiency of the } \\
\text { jement of Indonesian after having } \\
\text { rallel to that of Sundanese, even } \\
\text { a month post-onset. The linguistic } \\
\text { er level of familiarity compared to } \\
\text { both the languages }\end{array}$ \\
\hline Keywor & tic recovery pattern \\
\hline $\begin{array}{l}\text { First Received: } \\
8 \text { February } 2019 \\
\text { Final Proof Received: } \\
\text { 26 September } 2019 \\
\end{array}$ & $\begin{array}{c}\text { Accepted: } \\
\text { 13 August } 2019 \\
\text { Published: } \\
\text { 30 September } 2019 \\
\end{array}$ \\
\hline \multicolumn{2}{|c|}{$\begin{array}{l}\text { How to cite (in APA style): } \\
\text { Nasrullah, R., Suganda, D., Wagiati, \& Riyanto, S. (2019). Recovery patterns and a linguistic } \\
\text { therapy model of Sundanese-Indonesian bilingual aphasia: A neurolinguistic study. } \\
\text { Indonesian Journal of Applied Linguistics, 9, 452-462. doi: } 10.17509 / \text { ijal.v9i2.20243 }\end{array}$} \\
\hline
\end{tabular}

\section{INTRODUCTION}

In the perspective of neurolinguistics, language is not managed by the entire left hemisphere of the human brain (Pinker, 1994: 307). Such a condition has long been understood by experts, precisely after Paul Pierre Broca published results of his review of one of his patients in 1861. In his publication, Broca stated that the patient, having a certain disorder in the left hemisphere of his brain, experienced impaired speech. In terms of lingual expression, this patient had trouble in producing language sounds, which was not as usual. Not long after Broca's finding, Wernicke and Jules Dejerin confirmed Broca's theory. Various findings published about the language pathology symptoms have proven that there is a close connection between the human brain and language capacity. This basis also finally has given rise to a classical theory that exists in the field of neurolinguistics, namely, the theory of localization.

Localization can be understood as an idea stating that one region of the brain has a close relationship with a single behavioral ability, such as seeing and speaking. This theory was born along with the publication of findings from some neuroscientists, that is, Paul Pierre Broca (1824-1880) and Carl Wernicke (1848-1905), who found that damage to certain part of brain is correlated with the loss of some types of linguistic abilities in their patients (in the case of aphasia). Damage to "Broca's area" may result in reduced 
speaking ability, even though the comprehension ability is rather undisturbed. Damage to the "Wernicke's area" may result in reduced ability to understand speech, although the ability to speak is relatively not affected (Crystal, 2015, p. 229).

The relationship between the human brain and language ability eventually attracted the attention of experts from other disciplines outside medical world to pursue it. Jakobson, Lecours, Lhermitte, and Bryans noted that this multidisciplinary approach to a language pathology called aphasia was first carried out by Th. Alajouanine, A. Ombredane, and Marguerite Durand in 1939. In the beginning, they studied a tendency for impoverishment of sound patterns existing in people with aphasia. Along with its development, studies establishing the relationship between human brain and language capacity as the objects continued to be carried out.

Furthermore, aphasia as a language disorder has attracted linguists to study it. The linguists' attention to aphasiology is very great. They expect, by studying aphasia, that information can be found to better understand normal language processes, patterns of language produced by people with aphasia, and how language processes occur in the brain.

Research on aphasia, both within the framework of aphasiology and within that of neurolinguistics, will be more interesting if it is brought to a more complex area, namely, bilingual aphasia. The discussion concerning bilingualism and multilingualism itself has become very complex. Basically, lingual practices are not something monolithic, but involve many aspects affecting the lingual practices itself. Thus, if aphasia, as an aspect, is associated with the symptoms of bilingualism, as another aspect, it will become a more complex and comprehensive discussion. In fact, it seems that the discussion concerning bilingual aphasia has not been much raised as an in-depth study, especially in the framework of the Indonesian language as the object of study. The complexity of bilingual aphasia can be seen in the emergence of some typical symptoms related to bilingualism itself. These problems include codeswitching, impaired translation (Paradis, Goldbaum, \& Abidi, 1982) or obsessive-compulsive spontaneous translation (Goldstein, 1983; Kauders, 1983), and codemixing (Peresman, 1984). These have made bilingual aphasia a more complicated problem.

In relation to bilingual aphasia in the context of an in-depth study in aphasiology and neurolinguistics, the central problems discussed cover at least a few main things, (1) is the mechanism of the brain in speaking bilingual the same or different for the two languages? (2) Between two languages mastered by people with bilingual aphasia, which language may be the first to recover? (3) what kind of rehabilitation pattern is suitable for recovery of language proficiency in bilingual aphasia cases?

Research about bilingual aphasia, especially in terms of the recovery of language proficiency, has converged to two main aspects: earlier age of language acquisition and familiarity of language use. Both aspects have important roles in the process of restoring the language proficiency of patients with bilingual aphasia. As for which aspects have more influence, there needs to be an in-depth and comprehensive study. This has become a topic of discourse among neuropsychiatrists around the world. Ribot in 1881 (Pearce, 1885) spawned the law of regression which says the first language of an aphasic patient tends to improve better than their second or third language in polyglot aphasia. Some cases were indeed found to be reinforcing Ribot's idea, but there are also many cases that do not prove it (Albert \& Obler, 1978 in Rohde, 2018). For example, Pitres (1895, cited in Pearce, 2005) found that the order of acquisition has nothing to do with which language recovers better. However, it is their dominant language which is more resilient to linguistic damage in bilingual aphasia cases, namely; the language often used in their daily lives before the onset of aphasia. It will be the most durable and will be the first to recover, while recovery of the other language will occur later.

Based on the factors stated by the experts above, it can be said that so far there is no universal rule that can explain the various symptoms and dynamics of rehabilitation of bilingual aphasia patients as there is no single factor that can be identified as a specific cause of the syndrome in certain bilingual aphasic patients. Therefore, the discussion concerning bilingual aphasia and the dynamics of its rehabilitation cannot be separated from the factors related to the language acquisition and the language use on the one hand, and the neurological factors on the other.

This is the background that prompted the authors to investigate a topic relating to bilingual aphasia which, in this case, was a single case study of a SundaneseIndonesian bilingual aphasia patient. That there are complex lingual symptoms in people with bilingual aphasia was also a consideration for the authors to raise this topic. In addition, as the authors know, so far research concerning this problem either within the framework of neurolinguistics or within that of linguistic aphasiology has not been conclusive on persons with bilingual aphasia in Indonesian (see Mehrpour, Motamed, Aghaei, Jalali, \& Ghoreishi, 2014; Gil \& Goral, 2004; Zanini, Angeli, \& Tavano, 2011; Tschirren et al., 2011; Berroir et al., 2017). Only a few people had written about this topic. However, the discussions are generally based more on information obtained through literature review and not based on research. Thus, through this paper, the authors tried to fill the gap by investigating verbal expressions produced by a person with Sundanese-Indonesian bilingual aphasia and his proficiency recovery pattern of the languages, and formulating the linguistic therapy model suitable for bilingual aphasia language proficiency rehabilitation. As it is deemed necessary to be revealed soon, the purpose of this paper is to investigate the recovery pattern and linguistic therapy model of bilingual aphasia. 


\section{METHOD}

This research was conducted with two approaches: a theoretical approach and a methodological approach. In terms of the theory, the approach used in this study was neurolinguistic. In terms of the methodology, the approach was analytic-descriptive with a cohort method in the form of an epidemiological research method used to study the dynamics of correlation between risk factors and effects, with a model of forward longitudinal approach, a prospective approach (Pratiknya, 2008: 184). Althrough this approach, the authors could discover the level of language proficiency development in a person with Sundanese-Indonesian bilingual aphasia.

This study focuses on a single case study by analyzing one Sundanese-Indonesian bilingual aphasia patient who was treated at one brain hospital in Jakarta, Indonesia with the initial name "AS", a 54-year-old man referred to the National Brain Center Hospital with the first diagnosis of Cerebrovascular Disease (CVD) Hemorrhagic Strokes (ICH EC CVD SH). After imaging, CT scan showed hyperdense lesions in the left temporal-parietal region. The data of AS were collected gradually in three stages. Stage 1 was acute period, which was 14 days post-onset. Stage 2 was two weeks post-acute. Stage 3 was done one month after Stage 1.

The use of an unstructured interview technique and the instrument was the chosen option in collecting data in addition to the elicitation technique. In addition, recording was frequently used in order that the speech data would be able to be heard again while processing them. The instrument for the assessment of the bilingual aphasia patient's language proficiency in this study was adapted from Bilingual Aphasia Test developed by Michael Paradis (2011).

The data obtained were analyzed by using a mixed method. The analysis of this study used the combination of two forms of approaches, namely qualitative and quantitative. Creswell (2010) states that mixed method research is a type of research that integrates qualitative and quantitative data. In this study, the qualitative method was used to describe the forms of verbal expression and lingual symptoms appearing in the utterances of the patient with Sundanese-Indonesian bilingual aphasia. As for quantitative method, it was used to assess the level of proficiency of the two languages, Sundanese and Indonesian, as a reference for evaluating bilingual proficiency.

\section{FINDINGS AND DISCUSSION \\ Case findings}

AS, a man born in the city of Bandung, is a native speaker of Sundanese (first language) who lives daily among Sundanese speakers. At the age of 18, AS continued his studies at the Institut Teknologi Bandung and finished at the age of 24. Although living and growing up among the Sundanese language speakers, AS presented an interesting language attitude, especially in terms of the preference of language use between the first language (Sundanese) and the second language
(Indonesian). The difference in the age of language acquisition between the first language and the second language was not far. AS began the acquisition of the second language (Indonesian) at the age of 6 in his formal elementary school. As for the acquisition of the first language, it was carried out naturally in the family context. At the age of 26, AS worked as a Part Instructor at an airline company. After his move to Jakarta, AS' lingual condition increasingly showed the dominance of the second language (Indonesia) in his life. An overview of AS' lingual condition can be seen in Table 1.

At age 54, AS had a Hemorrhagic Stroke Cerebrovascular Disease (CVD) (ICH EC CVD SH). CT scan showed hyperdense lesions in the left temporalparietal region. AS was referred to the National Brain Center Hospital since the fifth day post-onset.

For the research, data about AS' recovery were collected in three stages. Stage 1 was the acute period, which was 14 days post-onset. Stage 2 was two weeks post-acute. Stage 3 was a month after stage 1 .

\section{First evaluation (Two weeks post-onset)}

The first evaluation result was that AS was diagnosed with having expressive-receptive aphasia; he had lingual deficits in both the languages he mastered, Sundanese and Indonesian. The first evaluation result showed some of the lingual symptoms and verbal expressions of the patient (AS) that showed severe lingual deficits in both languages.

\section{(1) Verbal expressions}

Language production at this stage was very severe. AS could only produce utterances in Indonesian, but they were not informative and did not match the language function. Sundanese utterances could not be produced at all. The lingual symptoms in AS' utterances included the production of dominant neologistic jargon, word substitutions (verbal paraphasia and semantic jargon), as well as a severe form of unplanned pauses.

One of the lingual characteristics found in the utterances of people with bilingual aphasia is the production of neologistic jargon, that is, the use of new words that are not found in the dictionary (Kamus Besar Bahasa Indonesia). Another symptom in the utterances of bilingual aphasia is word substitutions (verbal paraphasia and semantic jargon). Both symptoms are related to errors in the use and retrieval of words as the substitutes for the target words. Sometimes the substitute words are recognizable, sometimes they are not. That the words can be recognized means that the substitute words can be predicted and associated with the target words. The relationship between substitute words and target words can be phonemic, morphemic, conceptual, or a combination of the three. Paraphasia in which the relationship between substitute words and their target words occurs phonemically / morphemically is classified into formal verbal paraphasia, while paraphasia in which the relationship between substitute words and the target words occurs conceptually is classified into semantic paraphasia. 
Table 1. Linguistic track record of the patient with Sundanese-Indonesian bilingual aphasia

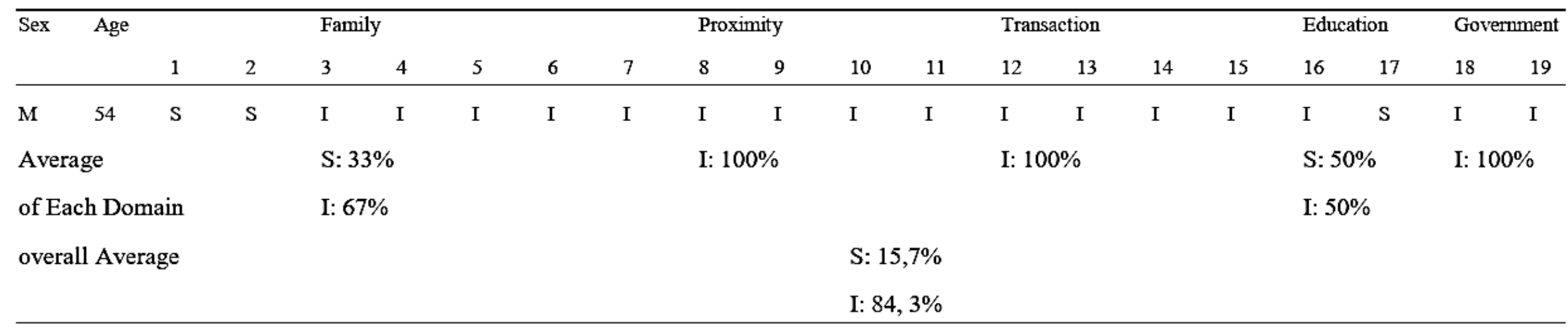

\section{S: Sundanese}

I: Indonesian

Family: (1) conversations with father/mother at home, (2) conversations with father/mother in center of crowd, (3) conversations with husband / wife at home, (4) conversations with husband / wife in center of crowd, (5) conversation with his child at home, (6) conversations with his child in center of crowd.

Proximity: (7) conversations with neighbors (old), (8) conversations with neighbors (young), (9) conversations with neighbors (of about the same age), and (10) conversations with neighbors' children.

Transaction: (11) conversations with ojek (taxi bike) riders known well by the patient, (12) conversations with unknown ojek riders, (13) conversations with shopkeepers known well by the patient, (14) conversations with unknown shopkeepers, and (15) conversations with traders in traditional market.

Education: (16) conversations with teachers in school and (17) conversations with teachers outside school.

Government: (18) conversations with urban village or sub-district civil servants in the office, and (19) conversations with urban village or sub-district civil servants outside the office. 
Another symptom is the production of semantic jargon. This symptom is meant as a mistake in taking words or mentioning words by replacing target words with substitute words, but the substitute words have no relationships at all with the target word, either phonemic, morphemic, conceptual or meaningful relationship. This phenomenon is almost similar to the symptom of the production of neologistic jargon. The difference between semantic jargon and neologistic jargon is the existence of the substitute words in dictionaries. In the case of neologistic jargon, the substitute words that replace the target words are not found at all in the dictionary, whereas in the case of semantic jargon, the substitute words that replace the target words can still be found in dictionaries.

The lingual symptoms can be seen in the following section.

a) Neologistic jargon, such as the saying of words like sambu, paring, pantah, popon, kulap, mulha, kunu, etc.

b) Verbal paraphasia

1. Formal Verbal Paraphasia (similarities in the initial phonemes, the initial syllables, and the final syllable):

\section{Substitute Words}

bayur (name of a tree in Indonesia)

bacang (name of a rice cake in Java)

2. Semantic Verbal Paraphasia

\section{Substitute Words}

gang (alley)

motor (motorcycle)

c) Semantic jargon

Substitute Words

paus (whale)

lampu (lamp)

bunyi (sound)

\section{(2) Utterances spoken}

AS could mention his name and his wife's correctly. As for comprehensively, he could only answer one spontaneous question (in Indonesian); his utterances
Target Words

sayur (vegetable)

bajaj (auto rickshaw)

\section{Target Words \\ jalan (street) \\ mobil (car)}

\section{Target Words \\ buah (fruit) \\ rumah (house) \\ rasa (flavor)}

were relatively smooth but not informative (logorrhea). AS' utterances can be seen in the following conversation.

P $\quad$ : Pak A, mas R kan belum kenal. Coba kenalin! Namanya siapa?

AS : Saya... nama AS. Terus?

I... my name is AS. And then?

$\mathrm{P} \quad$ : Istri bapak siapa namanya?

What is your wife's name?

AS : RN [mentioning his wife's name].

RN [mentioning his wife's name].

$\mathrm{P} \quad$ : Anak bapak?

Your child's?

AS : Nama saya, eh nama anak...

Istrinya? Eeeeh....

My name, eh.. my child's name

His wife's? Eeeeh.....

\section{(3) Mentioning names}

In the evaluation of mentioning names, AS had difficulty finding the words in both languages (Sundanese and Indonesian). In mentioning names of images, only 1 out of 5 items in Indonesian that he mentioned correctly, and he was unable to mention any item in Sundanese (the accuracy of the names in Indonesian was $20 \%$, while that in Sundanese was $0 \%$ ) as shown in Figure 1.

\section{(4) Following instructions}

As for the ability to follow instructions in the subtest that was carried out at the first evaluation, AS also experienced a severe disorder. He was able to carry out only 2 of $6(34 \%)$ orders in Indonesian, and was unable to carry out any instructions in Sundanese $(0 \%)$ as shown in Figure 1.

Based on the first evaluation results of AS, the following were finally determined.

a) The medium language of therapy chosen in the process of rehabilitation of AS' language competence was Indonesian (the second language)

The choice of the language of therapy adhered to Pitres' theory (Pearce, 2005) stating that language familiarity is the determinant factor of language recovery in patients with bilingual aphasia. The language most often used before 
the onset of aphasia will be the most durable language and will be the first language to recover, while restoration of other languages will occur later. In this study, based on the patient's lingual traces in Table 1 above, it is obvious that AS showed a dominance of Indonesian language use $(84.3 \%)$ compared to that of Sundanese $(15.7 \%)$. Thus, it may be concluded that AS has a high familiarity level of Indonesian before the onset of aphasia.

b) Since the first 2 weeks post-onset until a month post-onset (the second evaluation) the patient was given special treatment in his proficiency in Indonesian; the speech therapy was carried out in Indonesian.

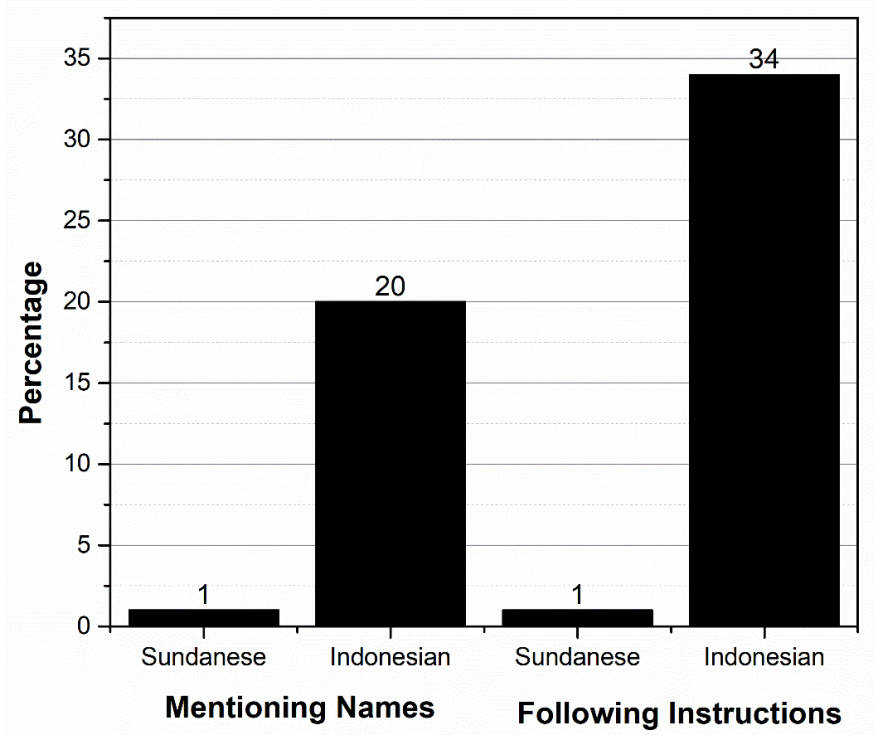

Figure 1. The Patient's lingual competence in both the languages at two weeks post-onset.

\section{Second evaluation (One month post-onset)}

After one month of speech therapy in Indonesian (L2), another evaluation was performed in both languages, Sundanese and Indonesian. Patients showed a significant increase in his lingual competence in both languages. After the second evaluation, AS was diagnosed of having dominant receptive aphasia in both languages.

a. Neologistic Jargon: gartu and dituk.

b. Semantic Verbal Paraphasia

Substitute Words

bangku (bench)

pelastik (plastic)

\section{(1) Verbal expressions}

In this phase, the patient's utterances in Indonesian increased significantly. The intensity of production of neologistic jargon decreased (producing only 2 utterances of neologistic jargon), even though the symptoms of verbal paraphasia still existed, especially semantic verbal paraphasia. In addition, there were still many symptoms of unplanned pauses (empty speech pauses and filled speech pauses) in this phase. The lingual symptoms can be seen in the following section.

c. Pause: Eeh, baa, kee, moo, apa namanya, apa tuh, apa, etc.

The interesting thing was that although the lingual symptoms above were not treated in Sundanese (L1) during the first month, in the second evaluation (a month post-onset), it was found that the patient began to show increased competence in Sundanese. However, they were still not informative and there were still many symptoms of verbal paraphasia in Sundanese.

\section{Target Words \\ kursi (chair) \\ kertas (paper)}

\section{(2) Utterances spoken}

In this subtest, AS could answer 3 of 5 spontaneous questions (in Indonesian) and still showed logorrhea symptoms in Sundanese (talkative, but not informative). The utterances in this phase also often showed symptoms of code-mixing between Indonesian and Sundanese. Sundanese (as the first language) sometimes appeared when he was speaking in Indonesian. The following are examples of these symptoms. 
kumaha itu dia tidak suka... maksudna, jangan sering, ameng... gitu. Main-main... gitu terus kedah be... be... belajar. Harus tahu yang harusnya, ulah terlalu TV saya tidak suka. Dia ter... tuh, kadang dia suka, TV gitu $y a !$

Oh, because I, $k a \ldots$ I am, right? Because I like, eh... I say... No, not too much... eeeh

Why does he not like that...? I mean, do not often play... like that. Playing... like that, then he must... study. He should know, do not [watch] TV too [much], I do not like. He..., sometimes he likes, TV, that's all!)

\section{(3) Mentioning names}

In the subtest of mentioning names in the second evaluation, AS showed increased competence in both languages (Sundanese and Indonesian). In mentioning the names of images, he was able to mention the names of 4 of 5 images in Indonesian (80\%) and only 2 of 5 images (40\%) in Sundanese as shown in Figure 2.

\section{(4) Following instructions}

In the subtest of mentioning names in the second evaluation, AS experienced increased competence in both languages (Sundanese and Indonesian). In mentioning the names of images, he was able to mention the names of 4 of 5 images in Indonesian $(80 \%)$ and only the names of 2 of 5 images $(40 \%)$ in Sundanese as shown in Figure 2.

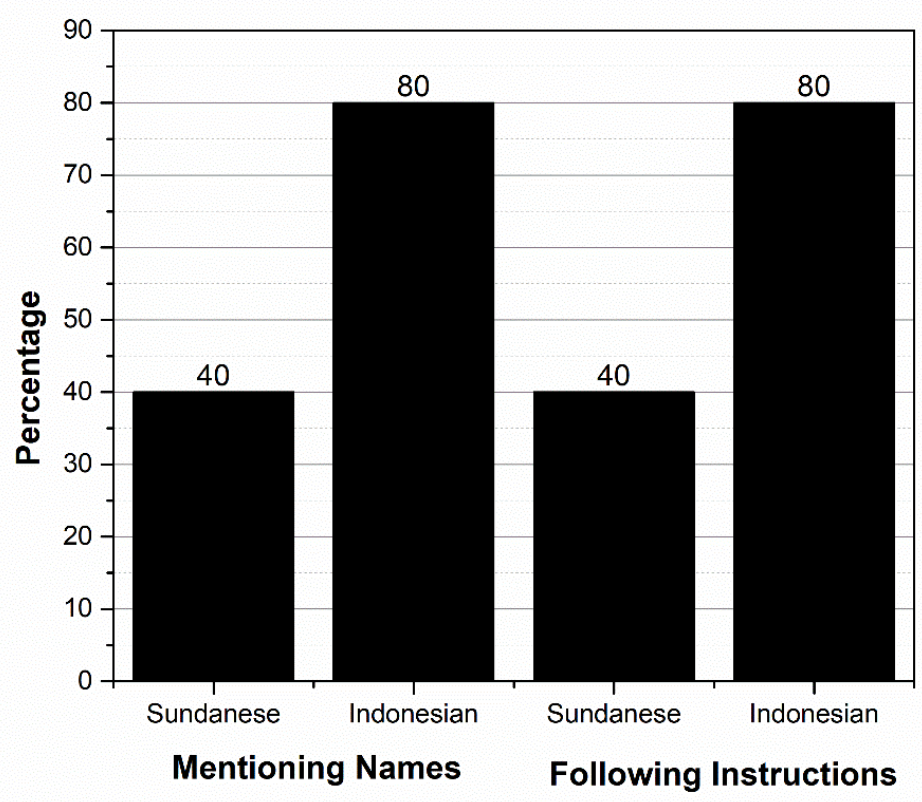

Figure 2. The patient's lingual competence in both the languages at one month post-onset.

From the result of the second evaluation (a month post-onset), the following was determined: because the result of the second evaluation showed an increase in language competence in Sundanese (whereas since the first evaluation until this point, no treatment was given to Sundanese), from the second evaluation to one and a half months post-onset, AS was given treatment to all the two languages (Sundanese and Indonesian) simultaneously.

\section{Third evaluation (One and a half months post-onset)} After simultaneous treatment to the two languages of
AS, another evaluation was carried out (one and a half months post-onset). At this stage, the evaluation result showed a different diagnosis of the competency of the two languages of the patient. AS was diagnosed with having expressive aphasia in Indonesian (the second language) and dominant receptive aphasia in Sundanese (the first language).

\section{(1) Verbal expressions}

AS's spontaneous utterances became more fluent in both languages. However, his utterances more showed functional aspects of Indonesian rather than Sundanese.

P : : Oke. Bagus pak. Coba disebutkan alat-alat transportasi pak!

Okay. Good sir. Try to mention transportation, sir!

AS : Becak, eh... bis... aduuuh. Be... becak, becak... astaghfirullah...

Pedicab, uh ... bus ... ouch. Pe ... pedicab, pedicab ... astaghfirullah ...

$\mathrm{P} \quad$ : Yang di udara?

the one in the air?

AS Bentang keluar... eh, pelayang.

The Star comes out... eh, pelayang 


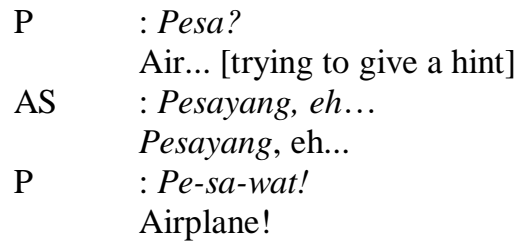

\section{(2) Utterances spoken}

In this subtest, AS could produce fluent utterances in Indonesian, but they were still not coherent. He could convey some information, even though there were still frequent symptoms of paraphasia. In Sundanese, the utterances were frequently produced with symptoms of empty utterances and pauses.

$\mathrm{P} \quad$ : ini gambar apa? (rumah di antara dua pohon kelapa)

What is this picture? (a house between two coconut trees))

AS : Rumah! Ya, rumah! Rumah ada, rumah ini ada... bukan ada bunga! Ini ada, ada untuk... bukan, bukan bunga ya? Karena ini tinggi, yang tinggi kayak gini namanya... ayam. Eh, bukan ayam. suka beli itu saya. Aduh.. dari apa ya?

House! Yes, house! The house is there, this house is there ... no flowers! This is there, there is for ... no, no flowers yes? Because it's tall, what is high like this is called ... chicken. Uh, not chicken. I used to buy it. Ouch .. from what?)

Tell me what you had done since this morning until I came!)

AS : Oya, saya tahu sekarang. Waktu itu saya... bangun jam lima malam, eh, pagi... jam lima pagi itu ya saya sholat. Kebetulan saya sholat, kebetulan saya ingin pergi jalan-jalan. Kebetulan di sini ada yang agak sedikit dingin, masih, masih agak-agak dingin jalan-jalan kita, karena waktu itu saya belum pernah, masih belum pernah keluar jalan-jalan. Maksudnya deket di rumah saya, gitu kan?

Oh yeah, I know now. At that time, I ... got up at five o'clock at night, uh, morning ... at five o'clock that morning, yes prayer. By chance, I prayed, by chance, I wanted to go for a walk. By chance, there was something/someone that was a little bit cold, still, it's still rather cold for our walk, because at that time I had never, still never, gone out for a walk. I mean near my house, right?)

\section{(3) Mentioning names}

In the subtest of mentioning names of the third evaluation, AS still had much difficulty in Sundanese, but its performance in Indonesian was better. He mentioned the names of 4 of 5 objects, 5 of 5 colors, and 3 of 5 forms. The total accuracy of $\mathrm{AS}$ in mentioning the names in Indonesian was 12/15 (80\%). As for mentioning names in Sundanese, he mentioned the names of 1 of 5 objects, 2 of 5 colors, and 1 of 5 forms. The total accuracy in mentioning names in Sundanese was 4/15 (26\%) as shown in Figure 3.

\section{(4) Following instructions}

The ability of AS to follow the instructions in in the third evaluation stagnated in Sundanese, while in Indonesian there was a significant increase. He could carry out 2 of $6(34 \%)$ instructions in Sundanese and 5 of $6(83 \%)$ instructions in Indonesian as shown in Figure 3 .

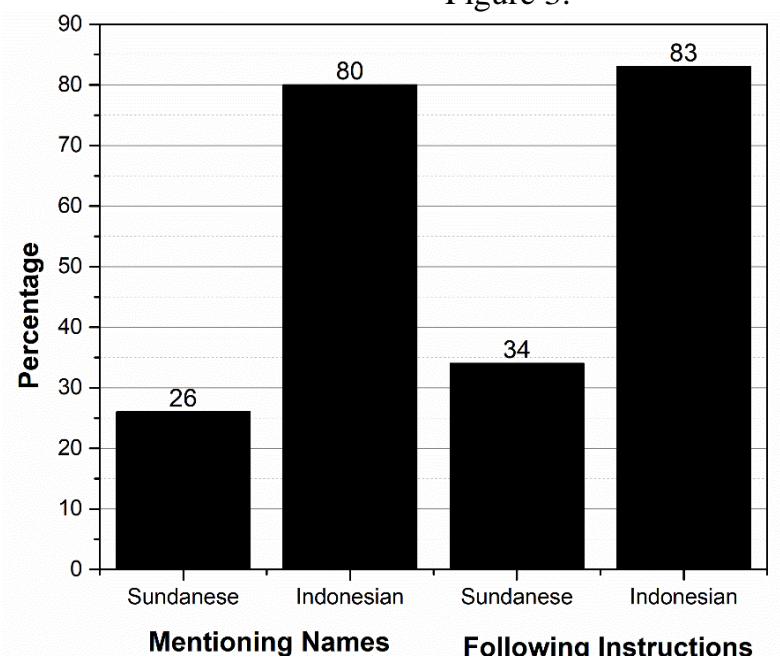

Figure 3. The patient's lingual competence in both the languages at one and a half months post-onset. 
After the third evaluation, it was determined that the recovery given to the patient would be greater in Indonesian than in Sundanese. And according to his wish, the language of therapy must focus on Indonesian.

\section{DISCUSSIONS}

This study reported the case of a person with Sundanese-Indonesian bilingual aphasia who experienced Hemorrhagic Stroke Cerebrovascular Disease (CVD) (ICH EC CVD SH) at the age of 54 years. He was diagnosed with having expressivereceptive aphasia in both languages. Three times evaluations of the ability of the two languages (in the period of one and a half months post-onset) showed an interesting recovery pattern. In the first evaluation (two weeks post-onset), the patient showed a nonparallel recovery; Indonesian (the second language) recovered earlier than Sundanese (the first language). However, in the result of the evaluation a month post-onset, the proficiency improvement in the languages showed a parallel recovery; Indonesian, that was chosen as the language of therapy, showed a recovery parallel with that of Sundanese, even though Sundanese was not given any treatment at all during the period of a month post-onset. Indeed, although there was an improvement in language proficiency in both languages, there were still lingual deficits in the forms of neologistic jargon, verbal paraphasia, semantic paraphasia, empty utterances, and pauses. The evaluation was carried out again one and a half months post-onset, and the result showed a parallel increase in the competence of each language he mastered. Quantitatively, the recovery of Indonesian (the second language) was more significant than Sundanese (the first language). However, qualitatively, the two languages showed the same patterns of deficits in proficiency.

\section{Bilingual aphasia recovery patterns}

Studies of bilingual aphasia generally show a parallel recovery pattern (Mortimer, 2000; Vilariño, Prieto, Robles, Leme, \& Noya, 1997). However, there are now many facts that show a variety of recovery patterns (Paradis, 2011). The explanation of the existing theories relating to the patterns of recovery from bilingual aphasia can be seen as follows.

Ribot (1881, cited in Pearce, 2005) stated that the aspect of the age of language acquisition is the determining factor in the recovery pattern of bilingual aphasia. According to him, the language learned earlier (the first language) would experience a recovery earlier than the language learned later. According to Ribot's law, then, in the context of bilingual aphasia, the language learned first may also be the language first recovering (Pearce, 2005).

Pitres (1895, cited in Pearce, 2005) has a conclusion that is different from that of Ribot. He proposed that the language most used during the period before the onset of aphasia will be the language first recovering. According to Pitres (1895, cited in Pearce,
2005), the aspect of language familiarity is the determining factor in the recovery from bilingual aphasia. Unlike Ribot (1881, cited in Kotik-Fiedgut, 2001) and Pitres (1895, cited in Pearce, 2005), Krapf (in Green et al., 2011) stated that the social environment and / or affection (emotional attitude) towards a language before or after brain injury may determine which language that recovers earlier.

A comprehensive opinion was proposed by Paradis (2011). According to him, the recovery of language proficiency in bilingual aphasia cannot be separated from several aspects: (1) suitability of the language with the situation, (2) the lesion severity, and (3) the differential reading knowledge of the language (e.g. Greek classic). Based on this view, Paradis (2011) finally offered six patterns of language recovery in patients with bilingual aphasia. The six patterns are as follows.

1) Parallel recovery; occurring when there are disorders in both languages with the same level of deficits and the same level of restoration.

2) Differential recovery; occurring when the languages recover relatively to the severity level of each of them.

3) Selective recovery; occurring when one of the languages is not restored. In mixed recovery, patients improperly mix their language. Nearly thirty percent of cases showed a selective recovery pattern (patients did not get back one or more of their languages).

4) Antagonistic recovery; occurring when, initially, one language competence recovers to a certain extent but then it begins to decline when another language begins to recover. An antagonistic recovery pattern is considered as the most uncommon recovery pattern.

5) Varied recovery; two languages can finally be restored but the recovery of the second language can only begin after the first is recovered, which is called sequential recovery.

6) Mixed pattern; the most uncommon recovery pattern that only happens casuistically.

By referring to the recovery pattern proposed by Paradis (2011), it can be intended that in this study AS experienced a differential recovery pattern; the two languages he mastered recovered relatively to their respective severity. In this case, Gill et al. (in Green et al., 2011) said that the existence of theoretical factors in respective individuals with bilingual aphasia, so that they can improve their language skills through what he called a "dynamic tree" from one symptom to another symptom. That means, for Gill et al. (in Green et al., 2011), the recovery pattern of bilingual aphasia is not something monolithic; many factors determine the recovery process. Based on the dynamic recovery approach, a patient with bilingual aphasia may experience different aphasia conditions in each period of onset, a repeated diagnosis needs to be done. For example, an individual might be initially diagnosed with 
having receptive expressive aphasia but, after a speech therapy process, then diagnosed with having dominant receptive aphasia, and then diagnosed with having expressive aphasia.

\section{Age and context of language acquisition}

Variables that might influence language recovery in patients with bilingual aphasia are age and context of language acquisition. In addition to Ribot (1881, cited in Pearce, 2005), Lambert and Fillenbaum (in Kiran, 2013) proposed that languages acquired in the same context may show parallel recovery and languages acquired at different ages and contexts may show non-parallel recovery (Gil \& Goral, 2004). However, the hypothesis of Lambert and Fillenbaum (in Gil \& Goral, 2004) does not apply to the patient in this study (AS). AS mastered Indonesian in the official education context (elementary school) while the Sundanese was mastered in another different context, namely the family context, so that Sundanese became the first language (mother tongue). Being mastered earlier than Indonesian, Sundanese, as his first language, should have recovered earlier. In fact, the patient's Indonesian, his second language, recovered earlier than his first language. It means that there was another factor that had more influence on the language recovery of AS.

\section{Language familiarity}

Another factor influencing language recovery in bilingual aphasia is language familiarity. Language familiarity was observed in the use of the languages before the onset in the patient with bilingual aphasia. Discussion concerning this factor can refer to the linguistic track record of the patient with bilingual aphasia. We could ask both the patient directly and his family about his use of the two languages before the onset of bilingual aphasia. Based on Table 1 above, AS had a relatively high level of familiarity in the Indonesian $(84.3 \%)$ compared to that in Sundanese $(15.7 \%)$. To measure the level of familiarity of the languages, we used the questionnaire instruments about the use and choices of the languages in the five realms of communication, i.e., family domain, proximity domain, transaction domain, education domain, and government domain.

Family domain was seen in six situations of communication: (1) conversations with father or mother at home, (2) conversations with father or mother in center of crowd, (3) conversations with husband or wife at home, (4) conversations with husband or wife in center of crowd, (5) conversations with his child at home, (6) conversations with his child in the center of crowd. Proximity domain was seen in four situations of communication: (1) conversations with neighbors (old), (2) conversations with neighbors (young), (3) conversations with neighbors (of about the same ages), and (4) conversations with neighbor's children. The transaction domain was seen in five communication situations: (1) conversations with entrepreneurs known by the patient, (2) conversations with unknown ojek (taxi bike) riders, (3) conversations with shopkeepers who were well known by him, (4) conversations with shopkeepers who were unknown to the patient, and (5) conversations with traders in traditional markets. The educational domain was seen in two communication situations: (1) conversations with teachers in his school and (2) conversations with teachers outside the school. And the domain of government was seen in two communication situations: (1) conversations with urban village or sub-district civil servants in the office, and (2) conversations with urban village or sub-district civil servants outside the office.

The linguistic track record of AS showed that Indonesian had a higher level of familiarity than Sundanese and it was correlated with the recovery process of both languages. Indonesian recovered earlier than Sundanese. Thus, language familiarity was the determining factor in the language recovery of AS at the National Brain Center Hospital, Jakarta.

Another interesting thing in AS' recovery process of Sundanese-Indonesian bilingual aphasia was the influence of the treatment towards the language of therapy (Indonesian) on the recovery of the language not used in the therapy (Sundanese). This was seen in the increase of lingual competence of Sundanese in the second evaluation, even though during the treatment process of the 2-week period of post-onset, Sundanese was not given any treatment at all. Does the factor of similarity between the structures of inter-languages in individuals with bilingual aphasia also have a significant influence on the language recovery process? To answer this question, more comprehensive and integrated studies with more patients should be done.

\section{CONCLUSION}

AS was an individual with Sundanese-Indonesian bilingual aphasia who experienced Cerebrovascular Disease (CVD) Hemorrhagic Stroke (ICH EC CVD SH) at the age of 54. He was diagnosed with having expressive-receptive aphasia in both languages. Three times evaluations of the proficiency of the two languages (during the period of one and a half months post-onset) showed an interesting recovery pattern. In the first evaluation (two weeks post-onset), the patient showed a nonparallel recovery; Indonesian (the second language) recovered earlier than Sundanese (the first language). However, in the result of the evaluation a month post-onset, it was found that the improvement in proficiency of the languages showed a parallel recovery; Indonesian, chosen as the language of therapy, showed a recovery that is parallel to Sundanese, even though Sundanese was not given any treatment at all during the first month of post-onset.

By referring to the recovery pattern proposed by Paradis (2011), it can be suggested that AS in this study experienced a differential recovery pattern; the two languages he mastered recovered relatively to their respective severities. 
AS mastered Indonesian in the context of official education (elementary school) while Sundanese was mastered in a different context, that is, family context, so Sundanese became the first language (mother tongue). In this case, Sundanese, which was mastered earlier than Indonesian, should have been the first language to experience an earlier recovery. However, this patient' Indonesian, as his second language, recovered earlier than Sundanese, his first language.

The linguistic track record of AS showed that Indonesian had a higher level of familiarity than Sundanese, and it was correlated with the recovery process of the two languages. Indonesian recovered earlier than Sundanese in AS. Thus, language familiarity was the determining factor in the language recovery of AS.

\section{ACKNOWLEDGEMENTS}

The authors thank all the study subjects, research staff and who participated in this work. This work was funded by Doctoral Dissertation Grants from the Indonesian Ministry of Research, Technology and Higher Education.

\section{REFERENCES}

Berroir, P., Ghazi-Saidia, L., Dash, T., Adrover-Roig, D., Benali, H., \& Ansaldo, A. I. (2017). Interference control at the response level: Functional networks reveal higher efficiency in the bilingual brain. Journal of Neurolinguistics, 43, 416. doi: 10.1016/j.jneuroling.2016.09.007

Creswell, J. W. (2010). Research design: Pendekatan kualitatif, kuantitatif, dan mixed. Yogyakarta: PT Pustaka Pelajar.

Crystal, D. (2015). Ensiklopedi bahasa: The Cambridge encyclopedia of language. Bandung: Nuansa Cendekia.

Gil, M., \& Goral, M. (2004). Nonparallel recovery in bilingual aphasia: Effects of language choice, language proficiency, and treatment. Intenational Journla of Bilingualism, 8(2), 2004, 191-219. doi: $10.1177 / 13670069040080020501$

Goldstein, K. (1983). Disturbances of language in polyglot individuals with aphasia. In M. Paradis (Ed). Readings on aphasia in bilinguals and polyglots. (p.455-464). Quebec, Canada: Didier. (Original work published 1948).

Green, D. W., Ruffle, L., Grogan, A., Ali, N., Ramsden, S., Schofield, T. ... \& Price, C. J. (2011). Parallel recovery in a trilingual speaker: the use of the Bilingual Aphasia Test as a diagnostic complement to the Comprehensive Aphasia Test. Clinical Linguistic \& Phonetics, 25(6-7), 449-512. doi: 10.3109/02699206.2011.560990

Kauders, O. (1983). On polyglot responses in a sensory aphasia. In M. Paradis (Ed.), Readings on Aphasia in Bilingual and Polyglots. (pp. 286-300). Quebec, Canada: Didier, (Original work published 1929).

Kiran, S., Sandberg, C., Gray, T., Ascenso, E., \& Kester, E. (2013). Rehabilitation in bilingual aphasia: Evidence for within- and between language generalization. American Journal of Speech-Language Pathology, 22, 298-309. 10.1044/1058-0360(2013/12-0085)

Kotik- Fiedgut, B. (2001). A systemic-dynamic lurian approach to aphasia in bilingual speakers. Communication Disorders Quarterly, 22(2), 100109. https://doi.org/10.1177/152574010102200206

Mehrpour, M., Motamed, M. R., Aghaei, M., Jalali, N., \& Ghoreishi, Z. (2014). Unusual recovery of aphasia in a polyglot Iranian patient after ischemic stroke. Basic and Clinical Neuroscience, 5(2), 173-175.

Mortimer, J. (2000). The role of explicit memory in supporting the bilingual lexicon. McGill Working Papers in Linguistics, 15, 65-72.

Paradis, M., Goldbaum, M., \& Abidi, R. (1982). Alternate antagonism with paradoxical translation in billingual aphasic patients. Brain and Language, 15(1), 55-69. doi: 10.1016/0093-934X(82)90046-3

Paradis, M. (2011). Principles underlying the Bilingual Aphasia Test (BAT) and its uses. Clinical Linguistics \& Phonetics, 25(6-7), 427-443. doi: 10.3109/02699206.2011.560326

Peresman, E. (1984). Spontaneous translation and language mixing in polyglot aphasia. Brain and Language, 23(1), 43-63. doi: 10.1016/0093934X(84)90005-1

Pinker, S. (1994). The language instinct: How the mind creates language. United States: William Morrow and Company.

Pratiknya, Ahmad Watik. (2008). Dasar-dasar metodologi penelitian kedokteran dan kesehatan (5th Edn.). Jakarta: Raja Grafindo Persada.

Rohde, A., Worrall, L., Godecke, E., O'Halloran, R., Farrell, A., \& Massey, M. (2018). Diagnosis of aphasia in stroke populations: A systematic review of language test. PloS ONE, 13(3). doi: 10.1371/journal.pone.0194143

Tschirren, M., Laganaro, M., Michel, P., Martory, M. D., Di Pietro, M., Abutalebi, J., \& Annoni, J. M. (2011). Language and syntactic impairment following stroke in late bilingual aphasics. Brain and Language, 119(3), 238-242. doi: 10.1016/j.bandl.2011.05.008

Vilariño, I., Prieto, J.M., Robles, A., Lema, M., \& Noya, M. (1997). A study of bilingual GalicianCastillian aphasic patients. Review of Neurology, 25, 1165-1167.

Zanini, S., Angeli, V., \& Tavano, A. (2011). Primary progressive aphasia in a bilingual speaker: a single-case study. Clinical Linguistics \& Phonetics, 25(6-7), 553-564. doi: $10.3109 / 02699206.2011 .566464$ 